\title{
Sosialisasi dan Pelaksanaan Vaksinasi COVID-19 serta Penerapan Disiplin Protokol Kesehatan (5M) pada Mahasiswa Sektor Petra dan Elim Jemaat GPM Rehoboth
}

\author{
Monike Hukubun*, Yesintha Tahalele, Rikarson Tasidjwa, Risty A.Hattu, Madelin Koljaan, \\ Maria A. Beruat, Indah Gracelia Tamtelahitu, \& Santy Leslesy
}

Universitas Kristen Indonesia Maluku, Indonesia

\begin{abstract}
Jemaat Rehoboth Klasis Pulau Ambon merupakan salah satu jemaat terbesar yang berada di wilayah pelayanan Gereja Protestan Maluku (GPM). Karena memiliki lokasi yang luas sehingga pegabdian kepada masyarakat dalam rangkaian Kuliah Kerja Nyata difokuskan kepada dua sektor pelayanan yaitu Sektor Elim dan Sektor Petra yang secara administratif berada di Kelurahan Wainitu tepatnya di kompleks Talake. Dalam konteks mitra ditemukan sejumlah mahasiswa perantauan yang menetap sebagai warga koskosan belum mengikuti vaksinasi dan dalam kesehariannya tidak menerapkan disiplin protokoler kesehatan. Penyabab utamanya adalah pihak mitra tidak terdaftar secara resmi pada RT/RW setempat dan tidak terdaftar secara resmi sebagai anggota Jemaat GPM Rehoboth sehingga tidak dilibatkan pada kegiatan-kegiatan jemaat. Berdasarkan persoalan mitra kelompok berinisyatif untuk membuka jejaring kerjasama dengan majelis jemaat agar melibatkan mahasiswa kos-kosan dalam kegitan vaksinasi yang nantinya akan berlangung. Serta kelompok melakukan sosialisasi dan pelaksanaan vaksinasi dan disiplin protokoler kesehatan kepada mitra. Sebagai langkah menciptakan kekebalan imunitas kelompok dan menciptakan masyarakat yang cerdas dalam menerapkan disiplin protokoler kesehatan, yang berguna dalam rangka mencegah penyebaran pandemi COVID-19.
\end{abstract}

Keywords: COVID-19; Vaksinasi; Protokol Kesehatan.

\section{Introduction}

Pandemi coronavirus 2019 atau dikenal sebagai COVID-19 adalah peristiwa menyebarnya penyakit coronavirus 2019 di seluruh dunia. Penyakit ini disebabkan karena coronavirus jenis baru yang diberi nama SARS-Cov, yang menimbulkan gejala utama berupa gangguan pernapasan. Wabah COVID-19 pertama kali dideteksi di kota Wuhan, provinsi Hubei, Tiongkok pada bulan desember 2019, dan ditetapkan sebagai pandemi, oleh organisasi kesehatan dunia World Health Organization (WHO) pada 12 Maret 2020. Awalnya penyakit ini dinakaman sementara sebagai 2019 novel corona virus (2019-nCoV), kemudian WHO mengumumkan nama baru pada 11 Februari 2020 yaitu Coronavirus Disease COVID-19) yang disebabkan oleh virus Severe Acute Respiratory Syndrome Coronavirus-2 (SARS-CoV-2) (Susilo, 2020). Hingga saat ini COVID-19 telah bermutasi secara ganda dalam ragam varian seperti alpha coronavirus (B.117), betha coronavirus (B.1.351), ghama coronavirus dan delta coronavirus (B.1617.2) (Orno, 2021).

Pada umunya pandemi COVID-19 telah menyebar di 223 negara dengan kasus terkonfirmasi sebanyak 202.608.306, meninggal sebanyak 4.293.591. Di Indonesia jumlah kasus terkonfirmasi sebanyak 3.718.821, meninggal sebanyak

\footnotetext{
* Corresponding author:

E-mail address: monikehukubun2013@gmail.com
} 
110.619 dan yang sembuh sebanyak 3.171.147 (Satuan Tugas Penanganan COVID-19, 2021). Dan pada khususnya di Maluku terkonfirmasi 13.997, meninggal 243, sembuh 10,741 (Satuan Tugas COVID-19 Maluku, 2021). Data sebaran dan konfirmasi COVID-19 yang telah disebutkan menunjukan bahwa dari aspek kesehatan pandemi COVID19 sangat berbahaya bagi kehidupan manusia, karena penularan kasusnya yang cepat dan mengancam kehidupan sampai tahap kematian.

Dalam rangka pencegahan, pengendalian dan penanggulangan pandemi COVID-19, secara global berbagai elemen telah berupaya keras memutuskan mata rantai penyebaran pandemi COVID-19. Mulai dari pelaksanaan Pembatasan Sosial Berskala Besar (PSBB), Pemberlakuan Pembatasan Kegiatan Masyarakt (PPKM), bahkan ada negara-negara yang menerapkan lockdown. Ketika Pemerintah Indonesia menetapkan status kedaruratan kesehatan opsi yang dipilih ialah PSBB. Hal ini kemudian diterjemahkan oleh Pemerintah Maluku pada umunya dan Kota Ambon pada khususnya dengan penerapan Pembatasan Kegiatan Masyarakat (PKM) diikuti dengan kebijakan PSBB dan selanjutnya pelaksanaan kebijkan PPKM berskla mikro yang saat ini sementara berlangsung. Selain itu pemerintah juga menghimbau agar masyarakat tetap menaati protokoler kesehatan 5M (Memakai masker, menjaga jarak, mencuci tangan, mengurangi mobilitas dan menjahui kerumunan). Universitas Kristen Indonesia Maluku (UKIM) lewat Kuliah Kerja Nyata (KKN) pada masa pandemi juga diprogramkan untuk dilaksanakan pada kawasan tempat tinggal mahasiswa sehingga mempermudah pelaksanaan program kerja yang direncanakan serta memperpendek koordinasi dengan jemaat/masyarakat terkait. Mahasiswa juga didampingi secara online untuk bagaimana memprogramkan kegiatan-kegiatan serta menulis kronologis hasilnya berupa artikel hasil pengabdian masyarakat (Touwely, et.al., 2019).

Pencegahan, pengendalian dan penanggulangan pandemi COVID-19 juga diantasipasi dengan penggunaan vaksinasi kepada masyarakat. Di Indonesia program vaksinasi kepada masyarakat mulai dilaksanakan pada 13 Januari 2021. Ada 3 jenis vaksin COVID-19 yang digunakan di Indonesia sesuai rekomendasi World Health Organization (WHO) di antaranya : Sinovac 1 juni 2021, Sinopharm 7 Mei 2021 dan AstraZeneca-SK Bio 15 Februari 2021 (Talarima, 2021). Dasar pelaksanaan vaksinasi kepada masyarakat ialah penyebaran pandemic COVID-19 harus dikendalikan melalui kekebalan kelompok (herd immunity). Dengan demikian ketika sebagian besar populasi kebal terhadap penyakit menular akan memberikan perlindungan secara tidak langsung atau kekebalan kelompok bagi mereka yang tidak kebal terhadap penyakit tersebut (Kemenkes RI, 2021). Data Kemenkes (Kementrian Kesehatan) menunjukan bahwa vaksin secara nasional kepada masyarakat Indonesia per tanggal 23 Juli 2021 sebanyak 43.932 .287 untuk vaksinasi dosis 1 dan 17.253.709 untuk vaksinasi dosis 2. Provinsi Maluku secara khsus Kota Ambon program vaksinasi telah mencapai 40,1\% dengan jumlah 109.936 yang telah di vaksin (Kemenkes RI, 2021). Demi mencapai herd immunity maka proses vaksinasi perlu dilakukan secara masif baik oleh pemerintah maupun stakeholder lainnya (lembaga keagamaan dan lembaga pendidikan).

Pada Lokasi Mitra yang menjadi lokus pengabdian kepada masyarakat. Khususnya RT/RW 001/02 Kelurahan Wainitu sudah berpartisipasi untuk memutuskan mata rantai pandemi COVID-19. Di lingkungan sekitar telah dilaksanakan program vaksinasi yang dikhususkan kepada kategori lansia (lanjut usia) dan warga yang telah vaksin tahap pertama. Dalam hal ini pihak RT/RW membangun jejaring kerjasama dengan Puskesmas Kelurahan Benteng. Sebelum vaksinasi berlangsung pihak RT/RW melaksanakan sosialisasi vaksinasi dan penerapan disiplin protokoler kesehatan (5M) sebanyak dua kali kepada warga sebagai langkah memberikan pemahaman edukatif guna menjadi bekal bagi pekasanaan vaksinasi dan kehidupan sehari-hari.

Sebagai lembaga keumatan gereja juga turut berkolaborasi untuk memutuskan mata rantai penyebaran COVID-19. Idealnya, wabah ini disikapi dengan perpaduan antara pendekatan sains (ilmu pengetahuan, teknologi) dan agama. Sains dan teknologi digunakan sebagai ikhtiar untuk mencegah, mengobati dan menanggulangi dampak COVID-19 secara fisik, sedangkan agama memberikan asupan rohaniah agar manusia tetap tabah dan kuat secara spiritual (Muttaqin, 2020). Hal ini yang dilakukan gereja terkhusus jemaat GPM Rehoboth yang memahami tentang COVID19 secara spiritual dan akal sehat. Sebagai langkah memutuskan mata rantai penyebaran pandemi COVID-19 Jemaat GPM Rehoboth, tetap menghimbau jemaat untuk mengikuti program vaksinasi dan disiplin menati protokoler kesehatan 5M.

Kedepannya Jemaat GPM Rehoboth akan bekerjasama dengan Pemerintah Kota Ambon untuk penyelenggaraan vaksinasi. Kegiatan vaksinasi yang akan dilakukan dikhususkan hanya kepada perangkat pelayan dan anggota jemaat 
yang terdata pada data base. Karena itu, pendataan peserta vaksinasi hanya dilakukan bagi mereka yang resmi telah menjadi anggota Jemaat GPM Rehoboth. Dari data yang kami peroleh, ada sekitar 60 orang mahasiswa kos-kosan yang berada di Sektor Petra dan Elim belum mengikuti program vaksinasi. Mereka berdomisili di Jemaat GPM Rehoboth tetapi belum terdaftar secara resmi sebagai anggota jemaat. Karena belum melakukan asestasi dari Jemaat domisili awal. Sebagai prasyarat administratif perpindahan jemaat.

Secara geografis di wilayah mitra Sektor Petra dan Elim Jemaat GPM Rehoboth Klasis Pulau Ambon terdapat lembaga pendidikan yakni Sekolah Menengah Akhir (SMA) Muhammadiyah, Sekolah Menengah Kejuruan (SMK) dan Universitas Kristen Indonesia Maluku (UKIM). Oleh karena itu lokasi tersebut tidak saja dihuni oleh warga asli setempat, tetapi juga ditempati oleh para perantau yang datang untuk memperoleh pendidikan dan menetap sebagai warga kos-kosan.

Problematika mitra yang ditemukan dalam wilayah pelayanan Sektor Petra dan Elim antara lani : Pertama, sebagian besar warga kos-kosan yang menetap di wilayah fokus pengabdian belum terdaftar secara resmi sebagai anggota Jemaat karena dalam persyaratannya belum melampirkan surat atestase perpindahan jemaat. Kedua, Mahasiswa koskosan belum mendaftarkan diri pada RT/RW (001/02, 001/04, 002/02,002/04) Kelurahan Wainitu. Sehingga pada pelaksanaan vaksinasi yang dilakukan oleh RT/RW maupun yang nantinya akan dilakukan oleh Jemaat GPM Rehobot mereka tidak dapat berpartisipasi. Ketiga Sekalipun pihak pemerintah (RT/RW) dan gereja telah berupaya memutuskan mata rantai penyebaaran pandemi COVID-19 tetapi masih terdapat banyak mahasiswa kos-kosan maupun warga setempat yang belum secara baik menerapkan protokoler kesehatan. Sehingga permasalahan mitra tersebut mendorong kelompok untuk melakukan pengabdian kepada masyarakat dalam rangka sosialisasi dan pelaksanaan vaksinasi COVID-19 dan disiplin protokoler kesehatan 5M yang difokuskan kepada mahasiswa koskosan pada wilayah pelayanan Sektor Petra dan Elim Jemaat GPM Rehoboth Klasis Pulau Ambon, dengan tujuan memperkuat herd immunity untuk mencegah penyebaran pandemi COVID-19 dan cerdas dalam menerapkan protokoler kesehatan 5M dalam hidup sehari-hari.

\section{Permasalahan Prioritas Mitra}

Pada dasarnya kegiatan pengabdian dan pemberdayaan kepada masyarakat difokuskan dengan tema "Sosialisasi Dan Pelaksanaan Vaksinasi COVID-19 dan Protokoler Kesehatan (5M)". Mitra dari kegiatan tersebut adalah mahasiswa kos-kosan di Sektor Elim dan Petra Jemaat GPM Rehoboth Klasis Pulau Ambon. Dari hasil observasi dan wawancara ditemukan tiga permasalahan prioritas mitra di antaranya:

a. Mahasiswa kos-kosan belum mendaftarkan diri secara resmi pada RT/RW (001/02, 001/04,002/02,002/04 Kelurahan Wainitu) sehingga tidak dapat mengikuti vaksinasi yang diselenggarakan oleh RT/RW setempat.

b. Mahasiswa kos-kosan belum melakukan atestasi ke Jemaat GPM Rehoboth sehingga tidak dapat berpartisipasi pada pelaksanaan vaksinasi yang nantinya akan dilaksanakan oleh Majelis Jemaat. Karena fokus pelaksanaan vaksinasi Jemaat GPM Rehoboth hanya kepada anggota Jemaat yang ada di database.

c. Masih terdapat kos-kosan dan masyarakat setempat yang belum menerapkan displin protokoler kesehatan dalam hidup sehari-hari.

\section{Solusi Permasalahan}

Berdasarkan masalah prioritas mitra pada bagian 2 di atas maka ada tiga tawaran solusi untuk mengatasi permasalahan di antaranya :

1. Melakukan pendekatan kerjasama dengan RT/RW (001/02,001/04,002/02, 002/04 Kelurahan Wainitu) untuk mendata mahasiswa kos-koson. Agar secara resmi terdaftar sebagai warga RT/RW setempat.

2. Melakukan pendekatan kerjasama dengan Majelis Jemaat GPM Rehoboth agar memberikan kesempatan kepada mahasiswa kos-kosan di Sektor Elim dan Petra mengikuti vaksinasi yang akan diselenggrakan.

3. Implementasi kegiatan sosialisasi dan pelaksanaan vaksinasi COVID-19 dan penerapan disiplin protokoler kesehatan (5M) kepada mahasiswa kos-kosan di Sektor Elim dan Petra. 


\section{Metode Pelaksanaan}

Dalam rangka pengabdian dan pemberdayaan kepada masyarakat ada 3 tahapan metode pelaksanaan yang ditempuh meliputi :

a) Tahapan Persiapan

1) Melakukan Kordinasi dengan RT/RW (001/02,001/04,002/02,002/04) dan Mejelis Jemaat GPM Rehoboth untuk pemberitahuan pelaksanaan Kuliah Kerja Nyata dan Pengabdian Kepada Masyarakat.

2) Melakukan Observasi dan Wawancara Untuk Menemukan Permasalahan Mitra

3) Mempersiapkan Alat Peraga dan Instrumen Kegiatan Sosialisasi dan Pelaksanaan Vaksinasi COVID-19 dan Protokoler Kesehatan 5M

b) Tahapan Pelaksanaan Kegiatan

1) Observasi dan Wawancara:

Menurut Sukmadinata dan Nana Syaodih observasi merupakan pengamatan langsung pada suatu fenomena yang sedang berlangsung. Observasi diarahkan pada kegiatan memeperhatikan secara akurat, mencatat fenomena yang muncul, dan mempertimbangkan hubungan agar aspek dalam fenomena tersebut dapat dipahami lebih mendalam (Sukmadinata, 2013). Sementara wawancara adalah percakapan yang dilakukan oleh dua pihak, yaitu pewawancara (interviewer) yang mengajukan pertanyaan dan yang diwawancarai (interview) yang memberikan jawaban atas pertanyaan tersebut. Dengan tujuan memperoleh data dari fenomena yang diteliti Muttaqin (2020). Tujuan dari pelaksanaan wawancara dan observasi ialah kelompok dapat memperoleh informasi terkait dengan pelaksanaan vaksinasi COVID-19 dan displin protokoler kesehatan 5M yang dilakukan oleh mahasiswa kos-kosan pada Sektor Petra dan Elim.

2) Tahapan Pendataan, Kordinasi dan Pendekatan Dengan Majelis Jemaat dan RT/RW :

Setelah menemukan inti masalah prioritas mitra kelompok melakukan pendataan mahasiswa kos-kosan yang belum mengikuti program vaksinasi. Selanjutnya melakukan kordinasi dan pendekatan dengan Majelis Jemaat GPM Rehoboth untuk mengikut-sertakan mahasiswa kos-kosan dalam pelaksanan program vaksinasi yang nantinya akan berlangsung. Karena dari data yang diperoleh sekitar 60 mahasiswa kos-kosan yang berada di Sekotor Elim dan Petra belum mengikuti program vaksinasi.

3) Tahapan Sosialisasi dan Edukasi Protokoler Kesehatan 5M dan Vaksinasi Kepada Warga Sektor Elim dan Petra Termasuk Mahasiswa Kos-Kosan :

Pada tahapan ini metode pelaksanaan yang digunakan adalah webinar (menggunakan aplikasi zoom) ini dilakukan untuk mengantisipasi kerumunan. pembuatan flayer, penempelan stiker dan perekaman video edukasi vaksinasi protokoler kesehatan 5M serta pembagian masker kepada mahasiswa kos-kosan.

4) Pelaksanaan Program Vaksinasi Kepada Mahasiswa Kos-Kosan di Wilayah Pelayanan Sektor Elim dan

Petra:

Sebelum sampai pada tahapan pelaksanaan vaksinasi kelompok membuat whatsap grup dengan tujuan pendampingan dan melaksanakan fungsi kontrol terhadap peserta yang nantinya mengikuti vaksinasi. Selanjutnya kelompok mendampingi peserta untuk mengikuti proses vaksinasi yang dilaksanakan oleh Majelis Jemaat GPM Rehoboth Klasis Pulau Ambon.

C. Tahapan Monitoring dan Evaluasi Kegiatan :

Dari tahapan persiapan hingga tahapan pelaksanaan tidak ditemukan hambatan dan kendala. Semua metode yang digunakan dapat berlajan dengan baik adanya. Akan tetapi selepas kegiatan ini pendataan dan pendaftaraan mahasiswa kos-koson di lingkungan Sektor Elim dan Petra perlu ditingkatkan agar kedepannya dapat berpartisipasi dalam kegiatan-kegiatan baik yang diselenggarakan oleh Majelis Jemaat/Sektor maupun $\mathrm{RT} / \mathrm{RW}$. 


\section{Hasil dan Luaran yang Dicapai}

Dari solusi dan metode pelaksanaan kegiatan ada beberapa hasil dan luaran pencapaian yang di peroleh oleh kelompok yakni :

a) Observasi dan Wawancara:

Dari observasi dan wawancara indikator yang dicapau adalah kelompok menemukan permasalah utama yang dihadapi oleh mitra, sehingga memudahkan kelompok dalam menyusun rancangan dan instrumen penyelenggaraan kegiatan sosialisasi dan pelaksanaan vaksinasi dan disiplin protokoler kesehatan $5(\mathrm{M})$.

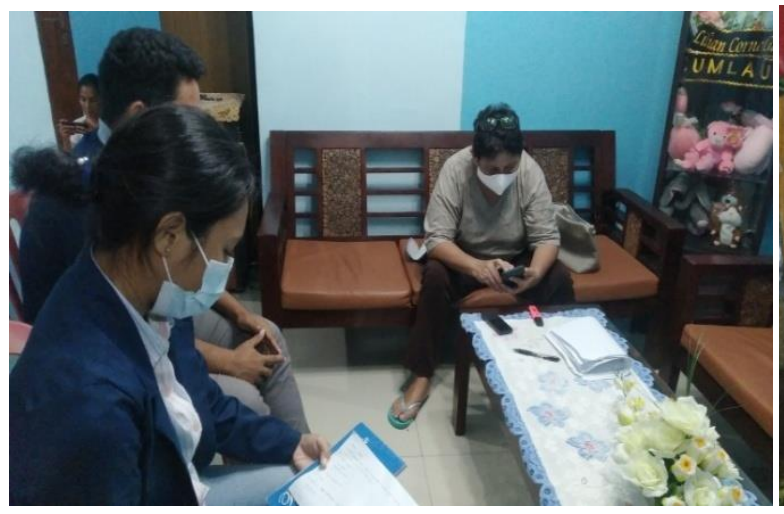

Gambar 1. Wawancara dengan Sekretaris RT

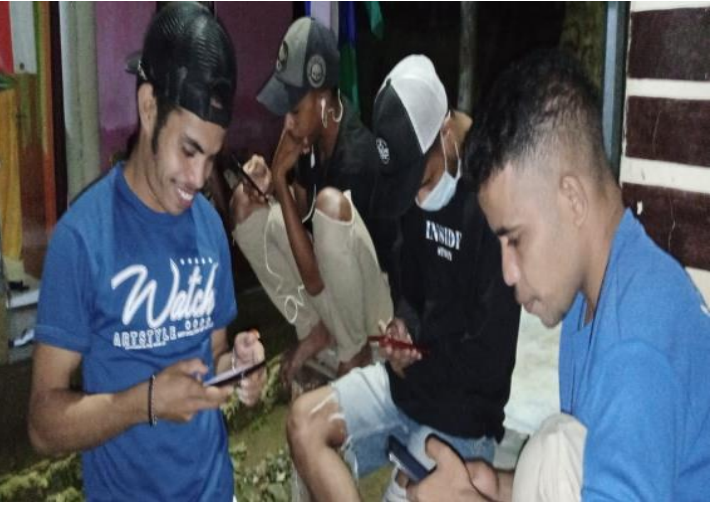

Gambar 2. Masyarakat Belum Menaati Protkes 5M

\section{b) Pendataan, Kordinasi dan Pendekatan Dengan Majelis Jemaat dan RT/RW :}

Hasil dari pendataan ditemukan sekitar 60 masiswa kos-kosan yang belum terdaftar sebagai masyarakat RT/RW setempat dan terdaftar sebagai anggota, serta belum mengikuti vaksinasi. Sehingga dari data tersebut memudahkan kelompok untuk berkordinasi dengan Mejelis Jemaat GPM Rehobot agar dapat menyertakan mereka dalam program vaksinasi yang akan berlangsung. Kelompok menganjurkan mitra untuk mendaftarkan diri pada RT/RW setempa agar dapat berpartisipasi aktif dalam kegiatan di waktu mendatang.
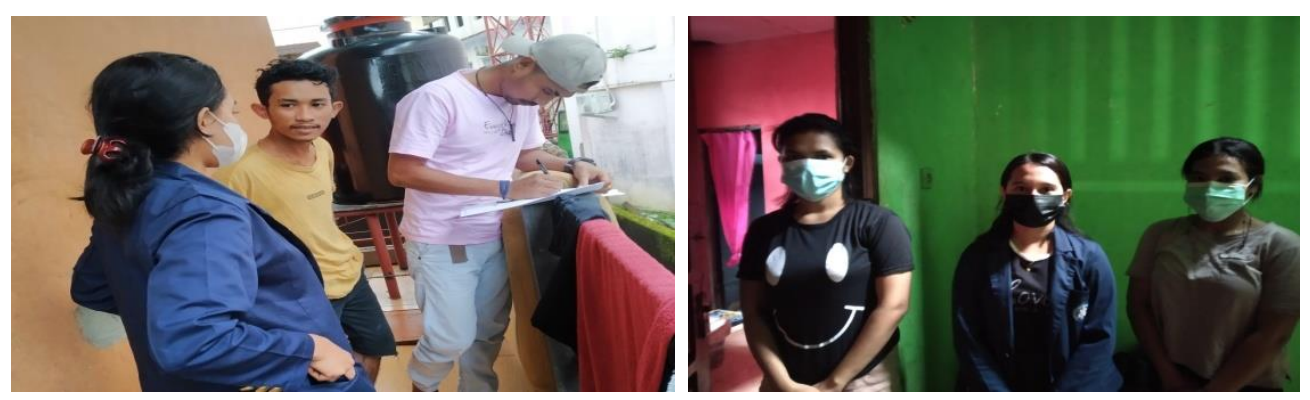

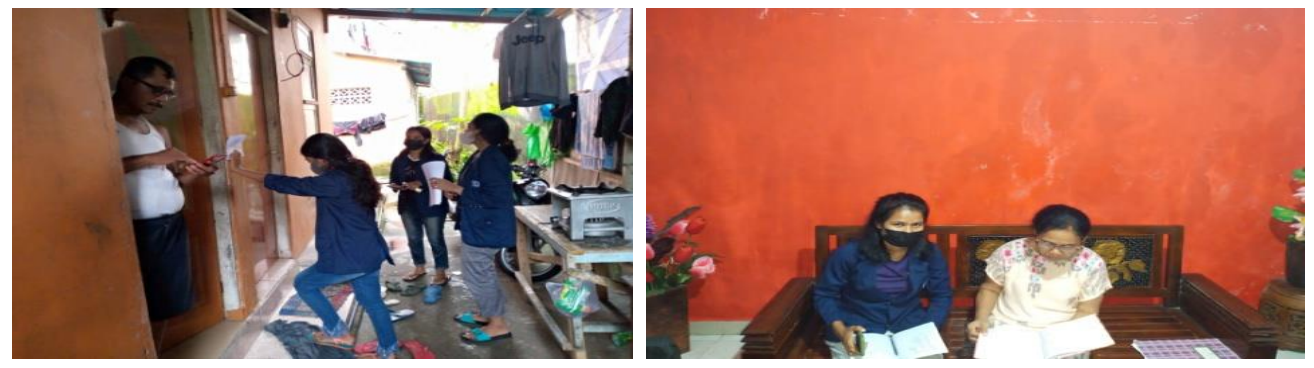

Gambar 3. Pendataan Mahasiswa

c) Sosialisasi dan Edukasi Vaksinasi COVID-19 dan Disiplin Protokoler Kesehatan 5M Kepada Mahasiswa KosKosan

Pada tahapan ini kelompok melaksanakan webinar pada tanggal 8 Agustus 2021 dengan tema "Edukasi Vaksinasi COVID-19 dan Protokoler Kesehatan (5M) dengan narasumber : Belytra Talarima, S.KM, M.Kes (Prespektif Kesehatan) dan Monike Hukubun, D.Th (Prespektif Teologi) secara kuantitas kegiatan ini dihadiri oleh 54 partisipan dan kualitas kegitan ini berjalan dengan baik diukur dari partisipasi aktif peserta webinar. Pembagian masker dilaksanakan pada tanggal 7 Agustus 2021 kepada 60 Mahasiswa kos-kosan. Pemasangan stiker dilaksanakan pada tanggal 7 Agustus 2021 di wilayah pelayanan Sektor Petra dan Elim dan Pengunggahan video edukasi vaksinasi COVID-19 dan disiplin protokoler kesehatan (5M) pada chanel youtobe "Rikarson Tasidjawa" Url: https://youtobe.be/qnbbiYtVPAQ. Demikian dapat disimpulkan bahwa kegiatan sosialisasi dan pelaksanaan vaksinasi COVID-19 dan protokoler kesehatan (5M) berjalan dengan maksimal. Sehingga luaranya ialah mahasiswa bersedia untuk mengikuti program vaksinasi dan memahami cara mengatasi penulran pandemi COVID-19 dengan disiplin protokoler kesehatan $(5 \mathrm{M})$.

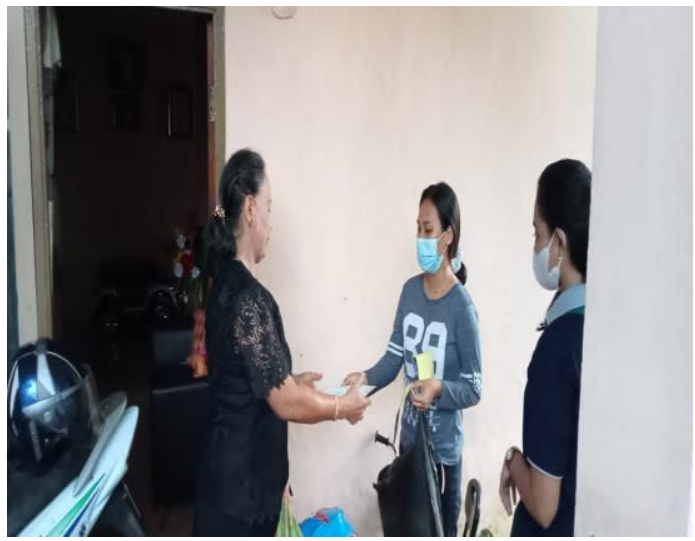

Gambar 4. Pembagian Masker

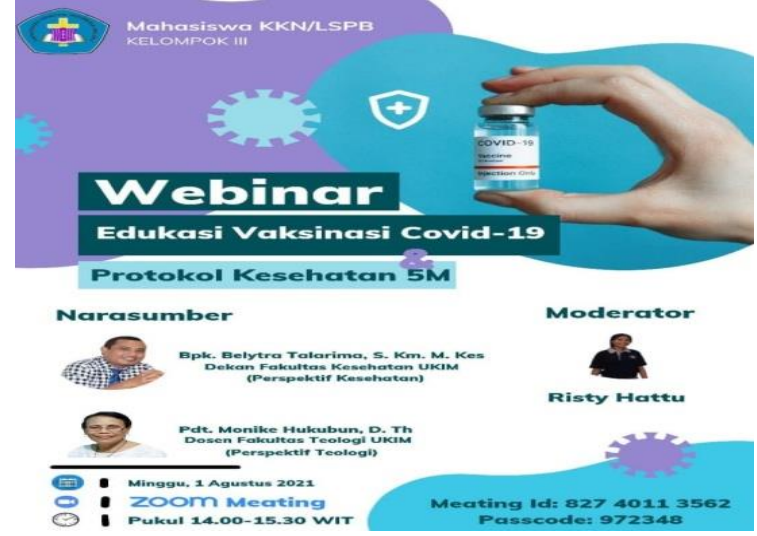

Gambar 5. Flyer Webinar 


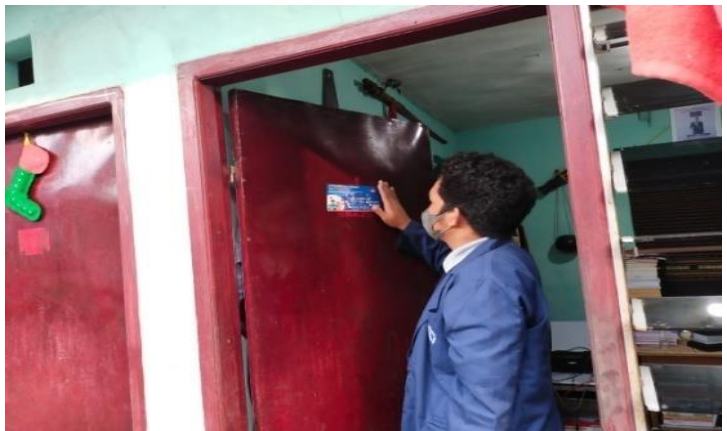

Gambar 6. Penempelan Stiker

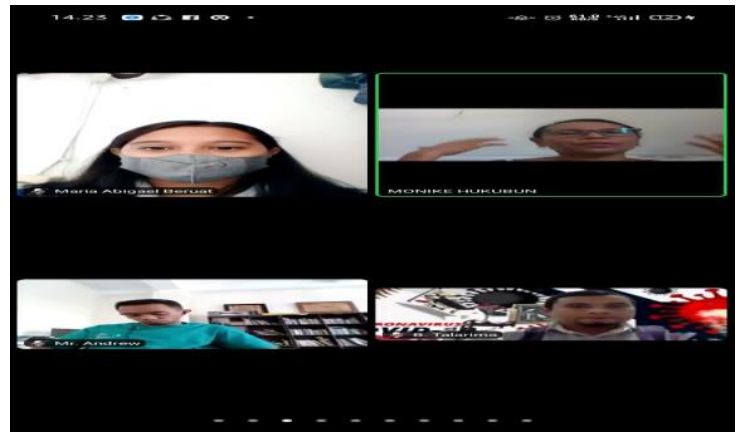

Gambar 7. Pelaksanaan Webinar

\section{d) Pelaksanaan Program Vaksinasi Kepada Mahasiswa Kos-Kosan di Wilayah Pelayanan Sektor Elim dan Petra.}

Kordinasi dengan Majelis Jemaat GPM Rehobot menghasilkan kemajuan yakni jemaat memberikan ruang bagi mahasiswa mengikuti program vaksinasi. Dari total 60 mahasiswa yang telah diedukasi. Terdapat 20 orang yang mendaftarkan diri untuk mengikuti vaksinasi. Sisanya sekitar 13 orang memiliki penyakit bawaan, sekitar 15 orang yang telah mengikuti vaksinasi di tempat lain yakni yang diselenggarakan oleh Ikatan Alumni Universitas Pattimura (IKAPATI) dan Program Vaksinasi kerjasama antara Gerakan Mahasiswa Nasional Indonesia (GMNI) bersama Polda Maluku dan sisinya memiliki alasan lain. Sehingga dari proses edukasi tersebut indikator capainya menghasilkan sekitar 58\% mahasiswa yang telah mengikuti program vaksinasi sehingga membantu terciptanya herd immunity.

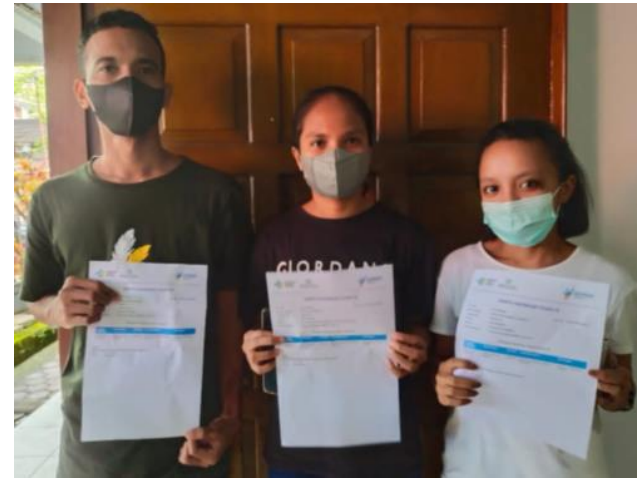

Gambar 8. Mahaasiswa yang telah selesai vaksinasi

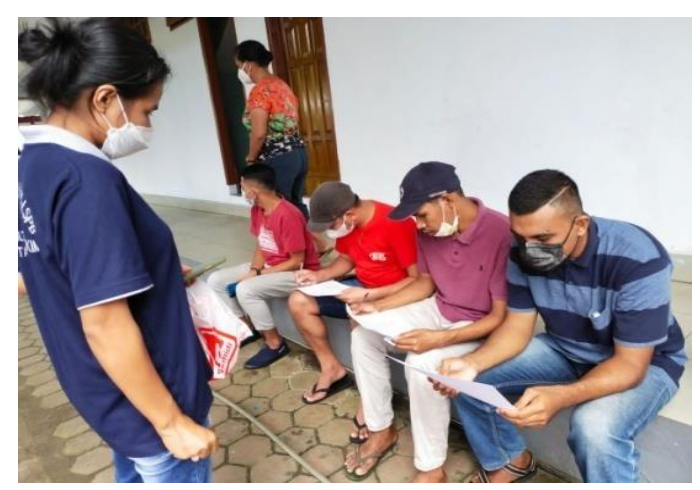

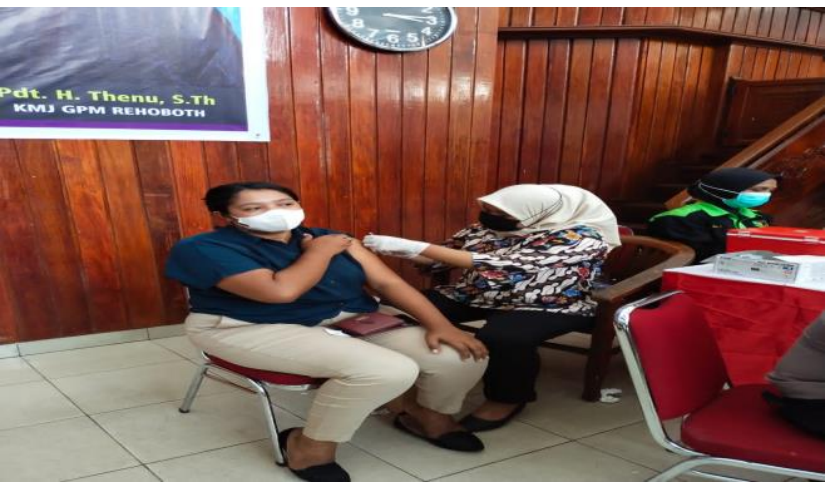

Gambar 9. Mahasiswa yang sementara di suntik vaksin

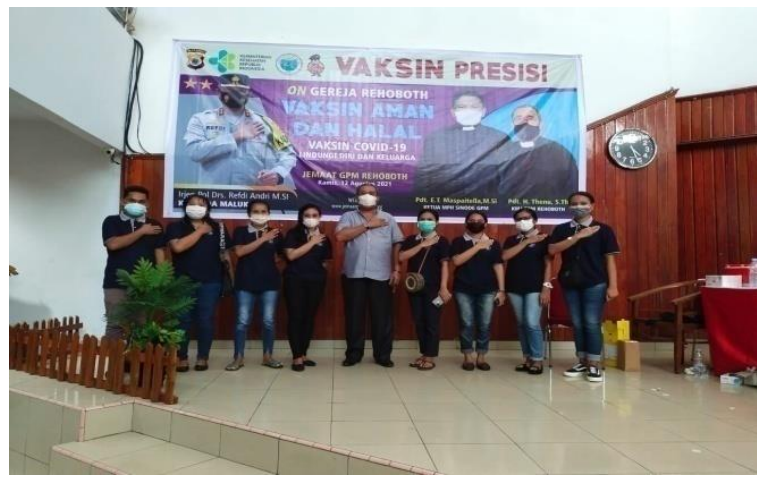


Gambar 10. Pengisian Formulir Vaksinasi Gambar 11. Foto Bersama Mahasiswa KKN dan KMJ Rehoboth

\section{Kesimpulan}

Demikian artikel pelaksanaan kegiatan pengabdian dan pemberdayaan kepada masyarakat ini dibuat. Semoga artikel ini dapat menjadi motivasi yang mendorong semangat mahasiswa Universitas Kristen Indonesia Maluku (UKIM) untuk tetap mengabdikan karya bagi masyarakat yang erupakan bagian dari basis tri dharma perguruan tinggi. Dan semoga capaian dari kegiatan ini menambah herd immunity dalam masyarakat serta terciptanya masyarakat yang cerdas dalam menerapkan dispilin protokoler kesehatan (5M) dalam rangka pencegahan, pengendalian dan penanggulangan pandemi COVID-19. Akhir kata biarlah kita semua tetap menjadi satu untuk memberitakan Kristus yang tersalib.

\section{References}

Kemenkes RI. (2021). Infeksi Emerging, Apa itu Herd Immunity? (Kekebalan Kelompok), diakses pada 23 juli 2021 Url: https://infeksiemerging.kemkes.go.id/uncategorizes/apa-itu-herd-immunity-kekebalan-kelompok

Kemenkes RI. (2021). Vaksin Ciovid-19 Nasional dan Maluku ( Data per tanggal 9 Juli 2021Pukul 18.00 WIT ) diakses tanggal 9 Juli 2021 Url: https://vaksin.kemenkes.go.id/\#/vaccines .

Muttaqin, A. (2020). "Nalar, Orientasi, dan Kedewasaan Beragama di Masa Wabah: Apa yang Dapat Studi agamaagama lakukan? agamaagama Lakukan ?" "Virus, Manusia, Tuhan: Refleksi Lintas Iman tentang COVID-19”, ed. Dicky Sofjan dan Muhammad Wildan, (Jakarta: KPG, 2020).

Orno, T. G. (2021). Mengenal Viru.s Corona (COVID-19) Varian Delta, diakses pada 10 Agustus 2021. url: https://jendralnews.org

Satuan Tugas Penanganan COVID-19. (2021). Data penyebaran pandemi COVID-19COVID-19 Global dan Nasional (Data per 10 Agustus 2021 Pukul 21.30 WIT), diakses tanggal 10 Agustus 2021 Url: https://COVID-19.go.id .

Satuan Tugas COVID-19 Maluku. (2021). Data penyebaran pandemi COVID-19 Provinsi Maluku (Data per tanggal 10 Agustus 2021 Pukul 22 WIT) diakses pada tanggal 10 Agustus 2021 Url: https://corona.malukuprov.go.id

Sukmadinata, N. S. (2013). Metode Penelitian Pendidikan. Bandung: Remaja Rosdakarya.

Susilo, A., et. al, 2020. Coronavirus Disease 2019: Tinjauan Literatur Terkini. (Jurnal Penyakit Dalam Indonesia Vol 7 No 1 Maret 2020, pp. 45-46.

Talarima, B. (2021). “COVID-19 : Cara Mencegah dan Mengatasinya” meteri webinar (9 Juli 2021)

Touwely, G. H., Nanuru, R. F., Laisila, M., \& Dandirwalu, R. (2019). "Assistance on Writing Scientific Papers for Students of Nusaniwe Village," Indones. J. Cult. Community Dev., vol. 4, no. 1, pp. 23-31, 2019, doi: 10.21070/ijccd.v2i3.70. 